\title{
Rancang Bangun Sistem Informasi Pengarsipan Data Pasien Klinik Cemara
}

\author{
Information System Engineering For Data Archiving Of Cemara Clinic Patient
}

\author{
Egia Rosi Subhiyakto*1, Yani Parti Astuti ${ }^{2}$, Liya Umaroh ${ }^{3}$, Danang Wahyu Utomo ${ }^{4}$, \\ Eko Hari Rachmawanto ${ }^{5}$, Christy Atika Sari, \\ 1,2,3, 4, 5, ${ }^{6}$ Program Studi Teknik Informatika, Fakultas Ilmu Komputer, \\ Universitas Dian Nuswantoro \\ J1. Imam Bonjol 207, Semarang \\ e-mail:*1egia@dsn.dinus.ac.id, ${ }^{2}$ yanipartiastuti@dsn.dinus.ac.id, ${ }^{3}$ liya.umaroh@dsn.dinus.ac.id, \\ 4danang.wu@dsn.dinus.ac.id, ${ }^{5}$ eko.hari.rachmawanto@dsn.dinus.ac.id, \\ ${ }^{6}$ christy.atika.sari@dsn.dinus.ac.id
}

\begin{abstract}
Abstrak
Pengelolaan data pasien pada sebuah rumah sakit atau klinik menjadi hal yang penting demi lancarnya aktivitas di rumah sakit atau klinik tersebut. Penelitian ini memiliki tujuan merancang Sistem Informasi Pengarsipan Data Pasien pada Klinik Cemara. Perangkat lunak yang dirancang memiliki fitur penambahan data diri pasien baru, menyimpan data diri pasien, menghapus data pasien yang sudah lama tidak berobat, serta mengupdate data diri pasien, jika sewaktu mendaftar ada ketentuan yang belum terpenuhi. Analisis kebutuhan sistem menggunakan analisis berorientasi objek dengan menggunakan diagram use case untuk menggambarkan fungsionalitas sistem, dan diagram kelas untuk menggambarkan hubungan antar kelas. Setelah dilakukan implementasi dan evaluasi hasil penggunaan aplikasi dilakukan pengujian baik secara alpha maupun beta. Pengujian dilingkungan pengguna menggunakan empat parameter yakni kebermanfaatan aplikasi, kemudahan dipelajari, kemudahan penggunaan dan kepuasan pengguna. Hasil evaluasi menunjukan bahwa $80 \%$ pengguna setuju aplikasi bermanfaat, $80 \%$ setuju aplikasi mudah dipelajari, dan $80 \%$ pengguna puas terhadap aplikasi tersebut. Bahkan $100 \%$ pengguna setuju aplikasi mudah untuk digunakan. Hal tersebut mengindikasikan bahwa aplikasi ini bermanfaat dan membantu dalam proses pengarsipan data pasien di Klinik Cemara.
\end{abstract}

Kata kunci: Sistem Informasi, Arsip, Pasien, Klinik

\begin{abstract}
Management of patient data in a hospital or clinic be important for smooth activity in the hospital or the clinic. This research has the goal of designing Information System for managing patient data on Cemara Clinic. Software designed features the addition of a new patient personal data, storing personal data of the patient, remove the patient data that has not been treated, as well as to update the personal data of the patient, if at any sign there is a provision that has not been met. Analysis of system requirements using object-oriented analysis using use case diagrams to illustrate the functionality of the system, and class diagrams to describe relationships between classes. After implementationmand evaluation of the results of testing applications use both alpha and beta. Testing environment users use four parameters namely the usefulness of the application, easy to learn, ease of use and user satisfaction. Results of the evaluation showed that $80 \%$ of users agreed helpful applications, $80 \%$ agreed the application is easy to learn, and $80 \%$ of users were satisfied with the application. Even $100 \%$ of users agreed the application easy to use. This indicates that this application is useful and helpful in the process of archiving patient data at Cemara Clinic.
\end{abstract}

Keywords: Information Systems, Archiving, Patient, Clinic 


\section{PENDAHULUAN}

Perkembangan teknologi informasi yang pesat menuntut organisasi atau institusi memiliki akses informasi yang cepat. Hampir semua kegiatan yang dilakukan membutuhkan informasi, hal tersebut mengakibatkan informasi menjadi hal yang vital dalam mendukung aktivitas administrasi maupun fungsi-fungsi dalam unit kerja lainnya. Arsip merupakan salah satu sumber informasi penting dalam menunjang kegiatan administrasi. Arsip juga berfungsi sebagai rekaman informasi, pusat ingatan, alat bantu pengambilan keputusan bahkan dapat juga sebagai bukti eksistensi sebuah organisasi. Di era teknologi saat ini kebutuhan informasi menjadi sangat penting, bahkan hamper semua organisasi maupun institusi memiliki sebuah sistem informasi. Dalam sistem informasi terdapat teknologi untuk menerima input, menjalankan model, mengakses data, menghasilkan dan mengirimkan keluaran serta membantu pengendalian sistem secara keseluruhan [1].

Klinik Cemara adalah salah satu Klinik yang berada di Kota Semarang, pengarsipan data pasien yang dilakukan di klinik cemara masih menggunakan metode konvensional dengan menggunakan media kertas sebagai bahan penyimpanan. Hal tersebut menjadi kendala dalam pencarian data pasien yang memerlukan waktu, bahkan arsip seringkali hilang atau tidak ditemukan. Dalam rekayasa perangkat lunak terdapat beberapa tahapan yakni pengumpulan kebutuhan, analisis, perancangan, implementasi, pengujian, pemeliharaan dan pengistirahatan perangkat lunak [2]. Proses pengembangan sistem informasi harus melalui beberapa tahapan tersebut agar diperoleh sistem informasi yang bermanfaat dan tepat guna. Untuk menjadi pengembang perangkat lunak yang baik dan kompeten harus diperoleh keterampilan yang mencakup semua tahap pengembangan [3]. Berdasarkan latar belakang sebelumnya dapat disimpulkan masalah yang terjadi adalah belum adanya sistem pengarsipan digital pada Klinik Cemara dalam mengelola data pasien yang berobat di Klinik Cemara. Penggunaan metode konvensional dalam pengelolaan data di Klinik Cemara menyebabkan pencarian data menjadi kurang efektif dan efisien. Penelitian ini memiliki tujuan merancang perangkat lunak Sistem Informasi Pengarsipan Data Pasien untuk mengelola data pasien pada Klinik Cemara. Perangkat lunak yang dirancang memiliki fitur penambahan data diri pasien baru, menyimpan data diri pasien, menghapus data pasien yang sudah lama tidak berobat, serta mengupdate data diri pasien, jika sewaktu mendaftar ada ketentuan yang belum terpenuhi.

Penelitian terkait yang sudah dilakukan diantaranya adalah [4] yang memaparkan tentang skema pengembangan sistem informasi, cara kerja dan perancangan basisdata yang dilakukan. Penelitian tersebut menghasilkan sistem informasi pengarsipan yang komprehensif, mempunyai nilai informasi dan sistem informasi pengarsipan tersebut dapat digunakan pada institusi yang berbasis layanan. Sistem informasi pengarsipan yang dibangun dapat meningkatkan level pengelolaan, efisiensi dalam bekerja dan meningkatkan utilisasi. Penelitian lain [5] memaparkan simulasi yang mengintegrasikan beberapa sistem informasi diantaranya sistem informasi rumah sakit, sistem informasi radiologi, dan sistem informasi pengarsipan gambar rekam medik pasien. Dalam penelitian tersebut menggunakan metode DICOM (Digital Imaging and Communication in Medicine) yang mana DICOM adalah sebuah prinsip berorientasi objek yang sangat penting dalam standarisasi data dan layanan dalam bidang medis. Hasil penelitian menunjukkan bahwa sistem dapat terintegrasi dengan baik dan menghasilkan solusi yang lebih baik.

\section{METODE PENELITIAN}

Metode yang digunakan dalam penelitian ini adalah metode eksperimen yang memusatkan pengamatan pada variabel dalam jumlah kecil dan bagaimana variabel terebut terpengaruh oleh kondisi dalam percobaan [6]. Dalam [7] dijelaskan bahwa proses penilaian penting dalam pengembangan perangkat lunak. Analisis kebutuhan sistem menggunakan metode analisis berorientasi objek yakni menggunakan Use Case Diagram dan Class Diagram. Implementasi 
menggunakan Bahasa pemrograman java dengan basisdata MySQL. Alat yang digunakan untuk membangun sistem adalah netbean untuk java dan SQLyog untuk database.

Metode pengembangan sistem menggunakan model waterfall. Karakteristik waterfall model adalah setiap tahap menghasilkan dokumen di akhir tahapnya, tidak ada overlapping, setiap tahap punya pengaruh besar terhadap hasil akhir di tahap berikutnya dan perlu biaya besar apabila rework. Gambar 1 menunjukkan model waterfall dimana fase awal adalah fase planning atau perencanaan dalam membangun sistem, analysis yakni fase menganalisa persyaratan apa saja yang dibutuhkan sebagai bagian dari memodelkan masalah, design atau perancangan adalah fase memodelkan solusi yang telah ditentukan berdasarkan kebutuhan sistem yang akan dibangun. Fase implementasi adalah fase dimana koding dilakukan sampai kemudian menjadi sebuah sistem. Setelah fase implementasi dilakukan pengujian sistem menggunakan metode black box dan strategi pengujian seperti dalam [2] baik secara top down maupun bottom up.

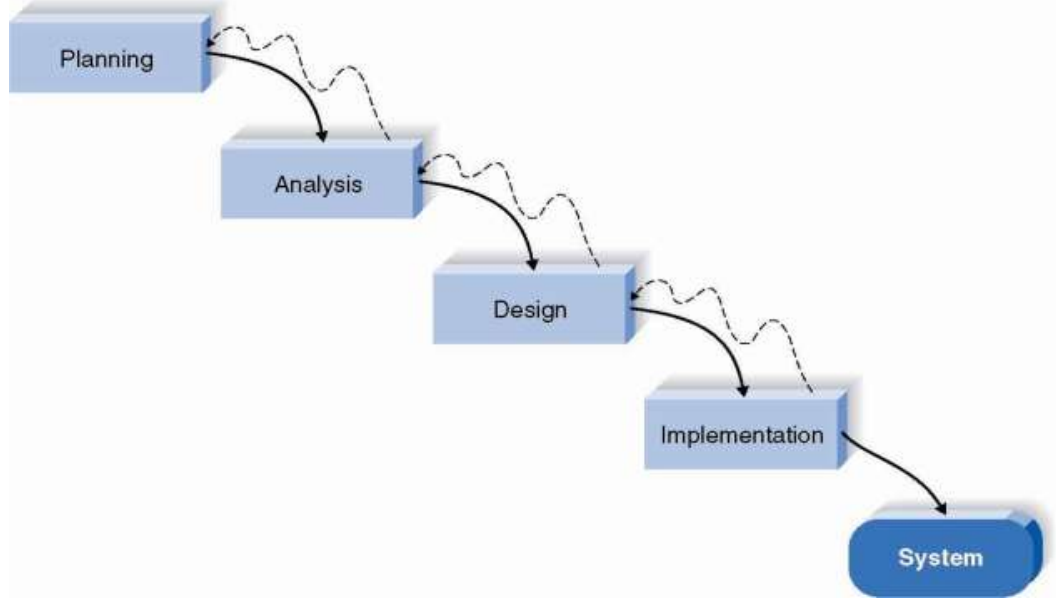

Gambar 1. Waterfall model (Alan Dennis dalam [8])

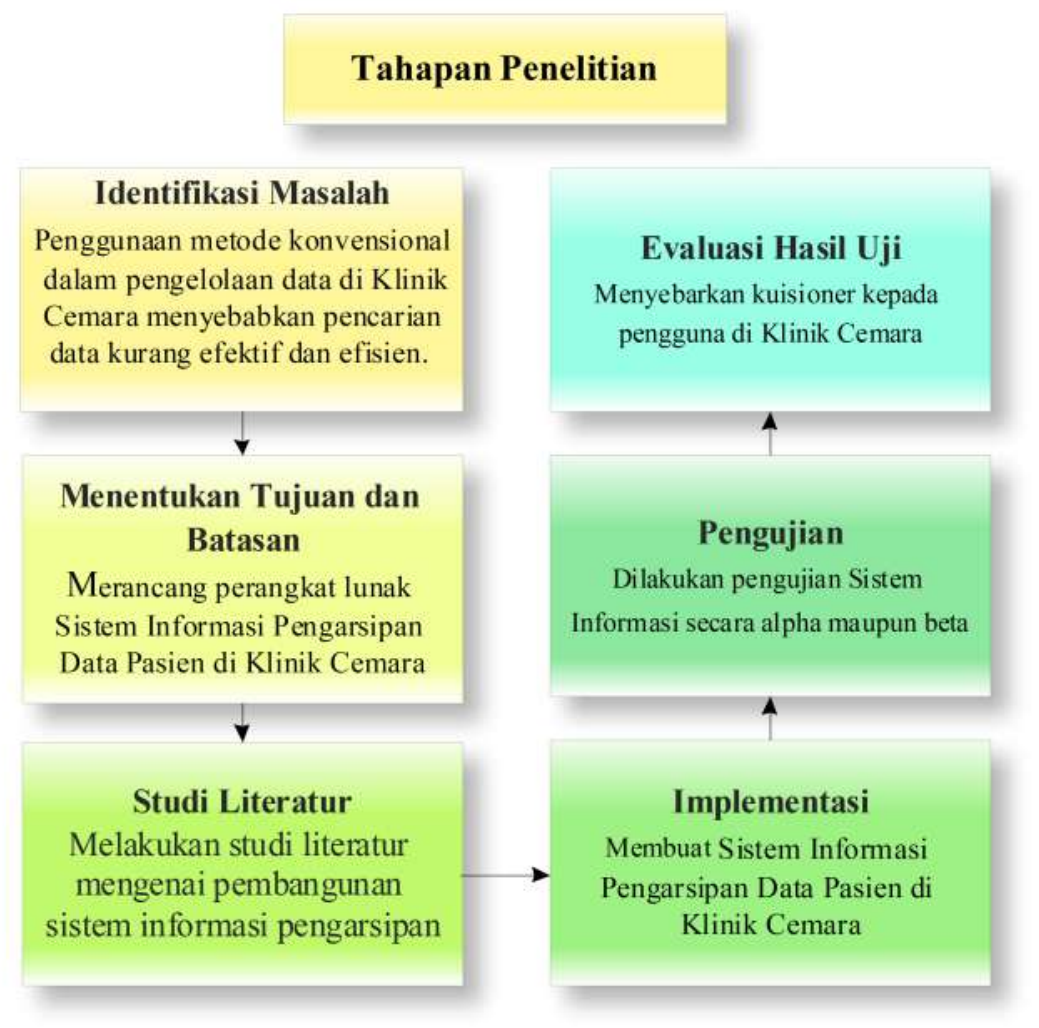

Gambar 2. Tahapan Penelitian 
Gambar 3 menunjukan arsitektur sistem informasi pengarsipan data pasien di Klinik Cemara yang terdiri dari tiga komponen yaitu: pengguna, antarmuka sistem dan basisdata. Komponen utama dari sistem ini adalah 1) pengelolaan data pasien, 2) pengelolaan data penyakit dan 3) pembuatan laporan. Pengguna sistem adalah administrator aplikasi dan dokter yang bekerja di klinik tersebut. Pengguna admin mempunyai hak akses dalam mengelola data pasien, mengelola data penyakit dan pembuatan laporan. Sedangkan dokter hanya mempunyai hak akses dalam pembuatan laporan.
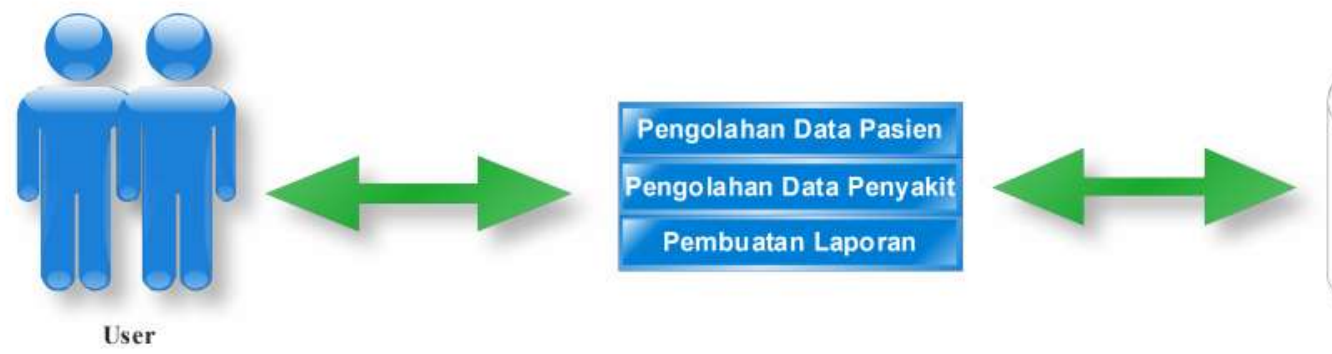

Gambar 3. Arsitektur Sistem Informasi

\section{HASIL DAN PEMBAHASAN}

\subsection{Analisis dan Perancangan Sistem}

Dalam tahapan analisis terbagi menjadi dua bagian yakni, analisis untuk kebutuhan fungsional dan analisis non-fungsional serta rancangan lingkungan implementasi.

\section{Deskripsi kebutuhan fungsional}

Diagram Use Case menggambarkan fungsionalitas sistem yang dibangun. Diagram Use Case untuk Sistem Informasi Pengarsipan Data Pasien Klinik Cemara ditunjukkan pada gambar berikut:

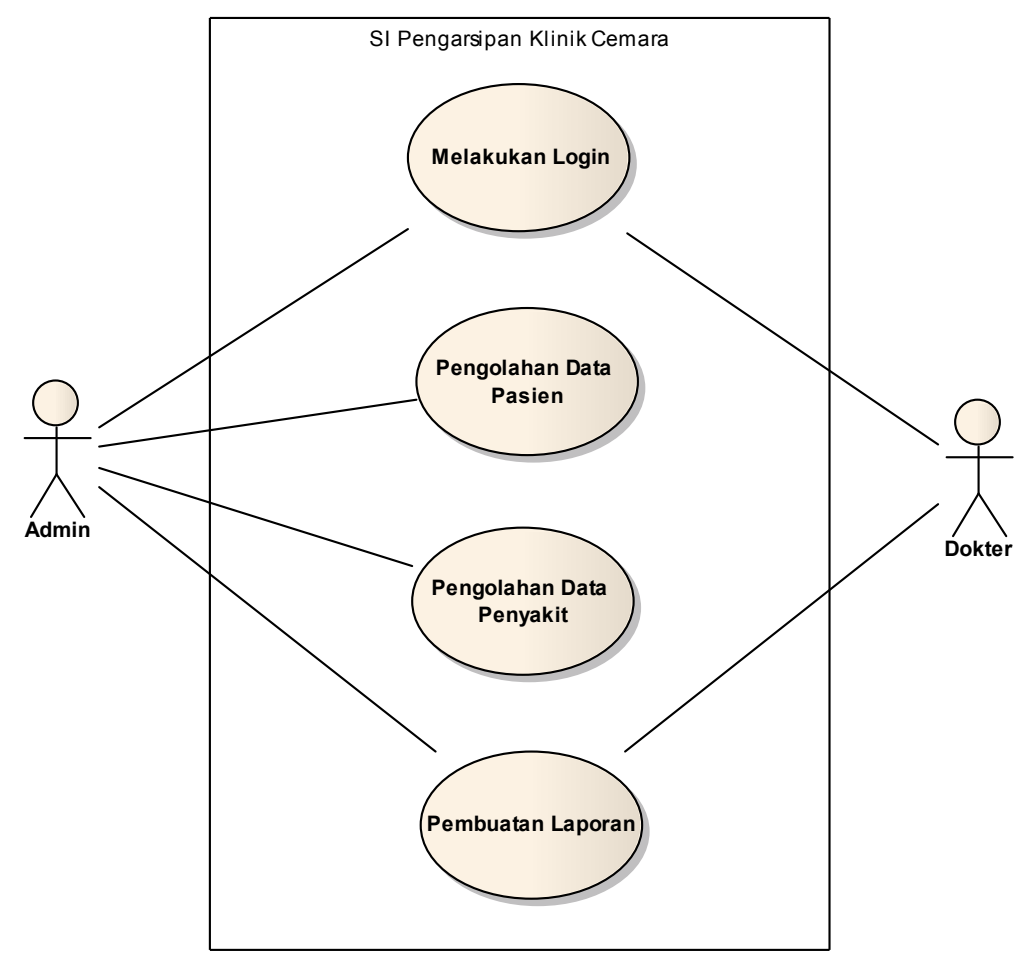

Gambar 4. Diagram Use Case 
Diagram Use Case menggambarkan fungsionalitas sistem, pada gambar 4 ditunjukkan bahwa diagram use case sistem informasi Klinik Cemara terdiri dari dua actor yaitu admin dan dokter, selanjutnya terdapat empat use case. Admin memiliki asosiasi dengan melakukan login, pengolahan data pasien, pengolahan data penyakit dan pembuatan laporan. Sedangkan dokter hanya memiliki asosiasi melakukan login dan melihat laporan.

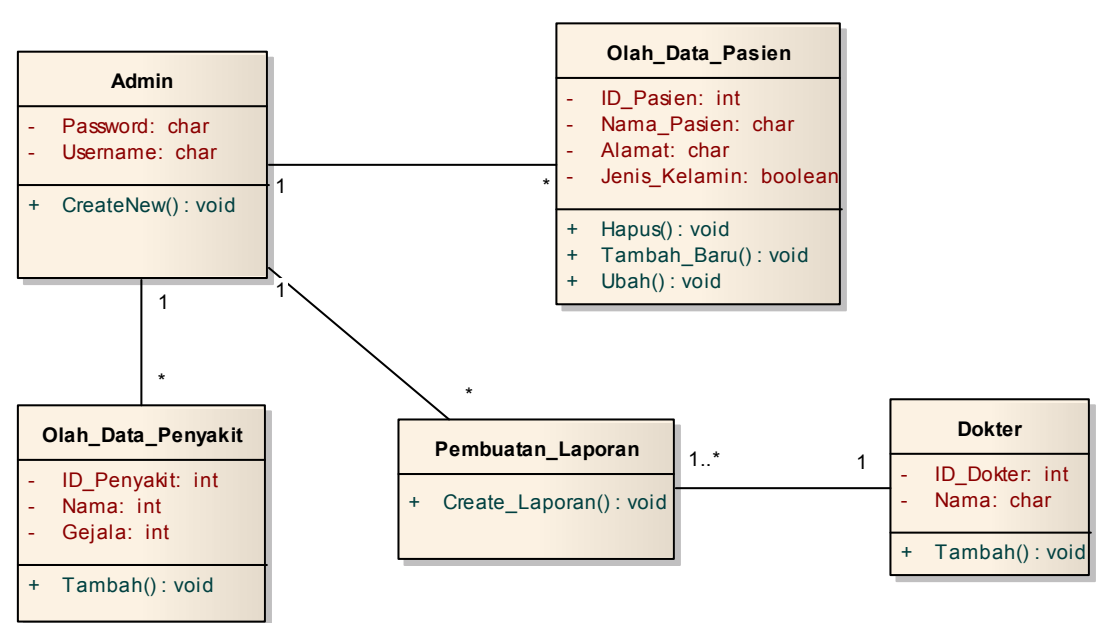

Gambar 5. Diagram Kelas

Diagram kelas menunjukan relasi antar kelas dan menggambarkan jenis objek dalam sistem dan berbagai macam hubungan statis yang ada di antara mereka. Setiap kelas yang terlibat masing-masing memiliki atribut dan operasi. Gambar 5 menunjukan terdapat kelas admin, dokter, olah_data_pasien, olah_data_penyakit dan pembuatan_laporan. Relasi terjadi antara admin dengan beberapa kelas seperti olah_data_pasien, olah_data_penyakit dan pembuatan_laporan dimana relasi/ multiplicity yang terjadi adalah one to many yang berarti satu admin dapat melakukan proses olah data pasien, olah data penyakit dan pembuatan laporan secara banyak/ berkali kali/ secara berkala. Sedangkan dokter hanya memiliki relasi ke kelas pembuatan_laporan dimana memiliki multiplicity one to one or more yang berarti seorang dokter dapat membuat laporan minimal satu kali tanpa ada batas maksimal.

\section{Deskripsi kebutuhan non-fungsional}

Selain kebutuhan fungsional sistem, juga terdapat analisis kebutuhan non-fungsional dari sistem yang akan dibangun. Deskripsi kebutuhan non-fungsional sistem informasi yang dibangun ditunjukkan dalam tabel 1 berikut:

Tabel 1. Deskripsi kebutuhan non-fungsional

\begin{tabular}{|l|l|}
\hline \multicolumn{1}{|c|}{ Kriteria } & \multicolumn{1}{c|}{ Tuntutan } \\
\hline Kinerja & Harus menerima inputan karakter maksimal 5 karakter per detik. \\
\hline & $\begin{array}{l}\text { Perangkat lunak yang dibuat dapat dioperasikan pad akomputer dengan } \\
\text { spesifikasi minimal Intel core i3, atu dengan RAM min 2GB dan Harddisk } \\
\text { minimum 500GB. }\end{array}$ \\
\hline Batasan Memori & Memori pada setiap data maksimal 5MB. \\
\hline Keamanan & Aplikasi hanya dapat dijalankan jika telah melakukan proses login. \\
\hline Modus Operasi & Semua file pendataan yang diisi oleh pasien akan disimpan ke dalam database \\
\hline Antarmuka & Semua data yang diisi haruslah jelas. \\
\hline & Setiap proses pendataan, satu data hanya untuk satu pasien. \\
\hline Batasan Data & Semua data yang diinputkan oleh pasien harus data asli. \\
\hline
\end{tabular}




\section{Perancangan lingkungan implementasi}

Spesifikasi lingkungan implementasi pengembangan perangkat lunak SI Pengarsipan Data Pasien Klinik Cemara akan diuraikan pada tabel 2-1. Spesifikasi tersebut meliputi sistem operasi, DBMS, development tools dan bahasa pemrograman yang dipakai.

Tabel 2. Lingkungan implementasi sistem

\begin{tabular}{|l|l|}
\hline \multicolumn{1}{|c|}{ Kriteria } & \multicolumn{1}{c|}{ Spesifikasi } \\
\hline Sistem Operasi & Windows XP/7/8 \\
\hline DBMS & My SQL \\
\hline Development tool & Netbeans \\
\hline Bahasa pemrograman & Java \\
\hline
\end{tabular}

\subsection{Implementasi}

Setelah tahapan analisis kebutuhan dan perancangan sistem, dilakukan tahap implementasi (proses koding) dengan menggunakan tool netbean dan bahasa pemrograman java. Berikut adalah tampilan antarmuka sistem informasi pengarsipan pasien di Klinik Cemara:

1. Tampilan Halaman Login

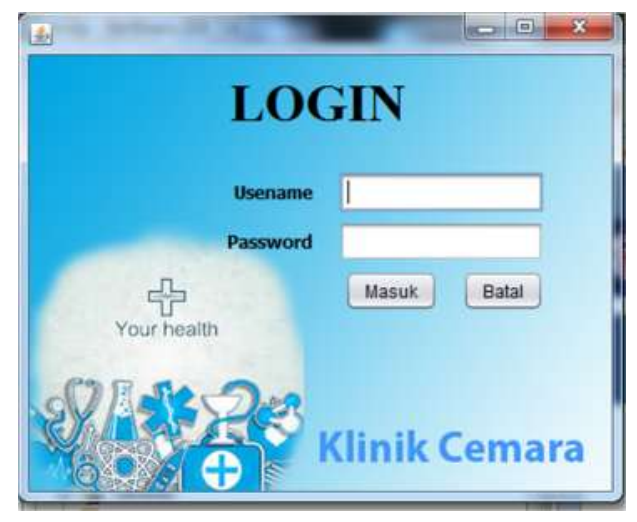

Gambar 6. Halaman Login

\section{Deskripsi Objek}

Tabel 3. Deskripsi objek halaman login

\begin{tabular}{|l|l|l|}
\hline \multicolumn{1}{|c|}{ Objek } & \multicolumn{1}{|c|}{ Jenis } & \multicolumn{1}{c|}{ Keterangan } \\
\hline User & Text pane & Memasukan user \\
\hline Password & Text pane & Memasukan password \\
\hline Masuk & Button & Untuk menuju validasi login \\
\hline
\end{tabular}

\section{Algoritma}

Input : User, Password

Proses : Jika memilih masuk return form validasi login

Output : validasi login berhasil 


\section{Tampilan halaman utama}

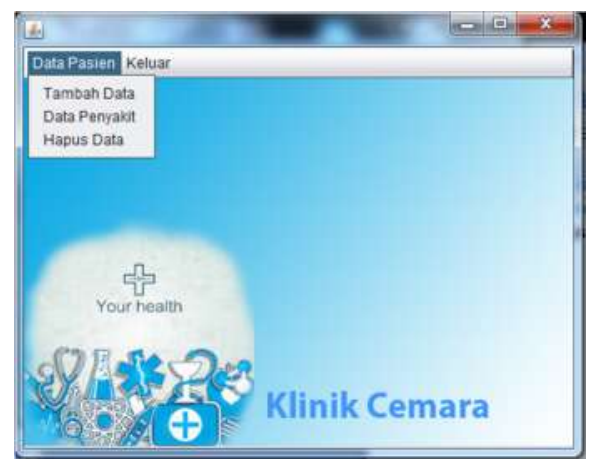

Deskripsi Objek

Gambar 7. Halaman Utama

Tabel 4. Deskripsi Objek halaman utama

\begin{tabular}{|l|l|l|}
\hline \multicolumn{1}{|c|}{ Objek } & Jenis & Keterangan \\
\hline Data Pasien & Menu Bar & Pilihan User \\
\hline Tambah Data & Menu item & Pilihan User \\
\hline Data Penyakit & Menu item & Pilihan User \\
\hline Hapus Data & Menu item & Pilihan User \\
\hline Keluar & Menu Bar & Menuju ke halaman login \\
\hline
\end{tabular}

\section{Algoritma \\ Input \\ Proses \\ : Jika memilih Data Pasien maka akan muncul pilihan Tambah Data return ke form Tambah Data jika memilih Data Penyakit maka akan return ke form Data \\ Output Penyakit, Jika Memilih Hapus Data maka akan return ke form Hapus Data.}

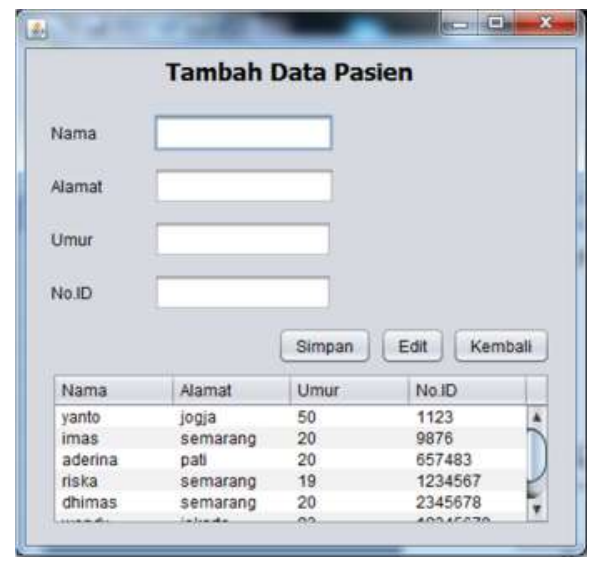

Gambar 8. Tampilan tambah data pasien

\section{Deskripsi objek}

Tabel 5. Deskripsi Objek Pemilihan Proses Input Oleh User

\begin{tabular}{|l|l|l|}
\hline Objek & Jenis & Keterangan \\
\hline Nama & Text pane & Input nama pasien \\
\hline Alamat & Text pane & Input Alamat pasien \\
\hline Umur & Text pane & Input Umur pasien \\
\hline No.ID & Text pane & Input No.ID pasien \\
\hline Simpan & Button & Menambah data pasien \\
\hline
\end{tabular}




\begin{tabular}{|l|l|l|}
\hline Edit & Button & Mengedit data pasien \\
\hline Kembali & Button & Kembali ke form halaman utama \\
\hline
\end{tabular}

\footnotetext{
Algoritma

Input

$:-$

Proses :

- Jika memilih button Edit maka akan retur ke form Edit data pasien

- Jika memilih button Simpan maka akan return ke form Menambah data pasien

- Jika memilih button Kembali maka akan return ke form Utama

Output : Inputan User, Pilihan User
}

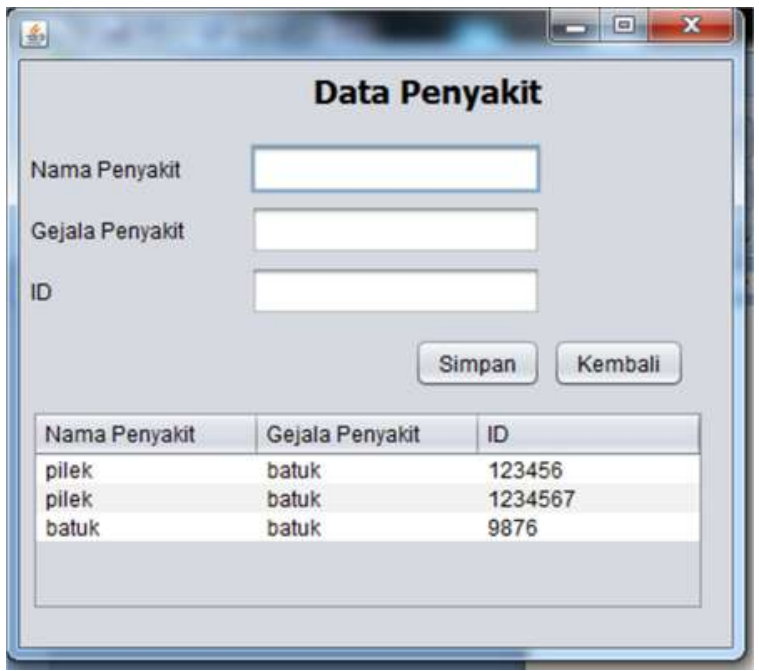

Gambar 9. Tampilan tambah data penyakit

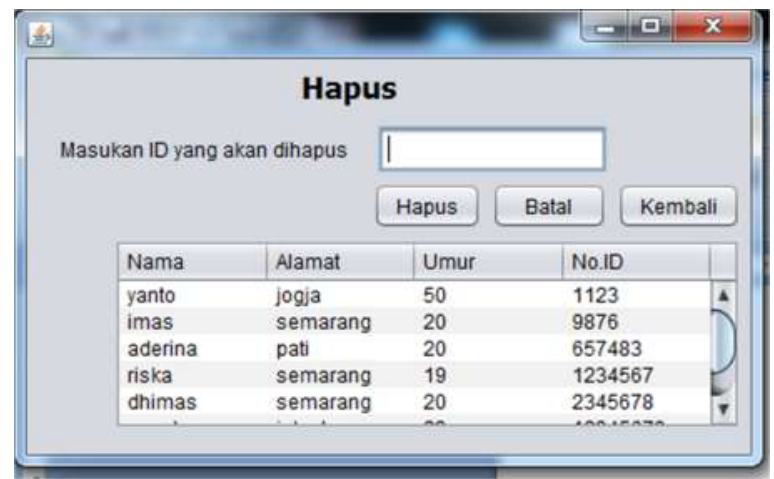

Gambar 10. Tampilan hapus data pasien

\subsection{Evaluasi Hasil}

Evaluasi hasil penelitian yang dilakukan adalah dengan cara melakukan pengujian aplikasi baik secara alpha. maupun beta. Pengujian alpha dilakukan dilingkungan developer, sedangkan pengujian beta dilakukan dilingkungan pengguna/ user. Evaluasi kemudian menggunakan kuisioner yang ditujukan untuk pengguna sistem dengan menggunakan skala likert skala 5 (sangat setuju, setuju, netral, tidak setuju, sangat tidak setuju). Perhitungan menggunakan rumus $\mathrm{Y}=\mathrm{P} / \mathrm{Q} * 100 \%$, dimana $\mathrm{P}$ adalah jumlah jawaban responden untuk setiap pertanyaan, $\mathrm{Q}$ adalah jumlah responden dan $\mathrm{Y}$ adalah nilai prosentase. Pertanyaan yang diberikan mencakup beberapa aspek antara lain kebermanfaatan aplikasi, kemudahan penggunaan, kemudahan untuk dipelajari, dan kepuasan pengguna dalam menggunakan aplikasi tersebut. 


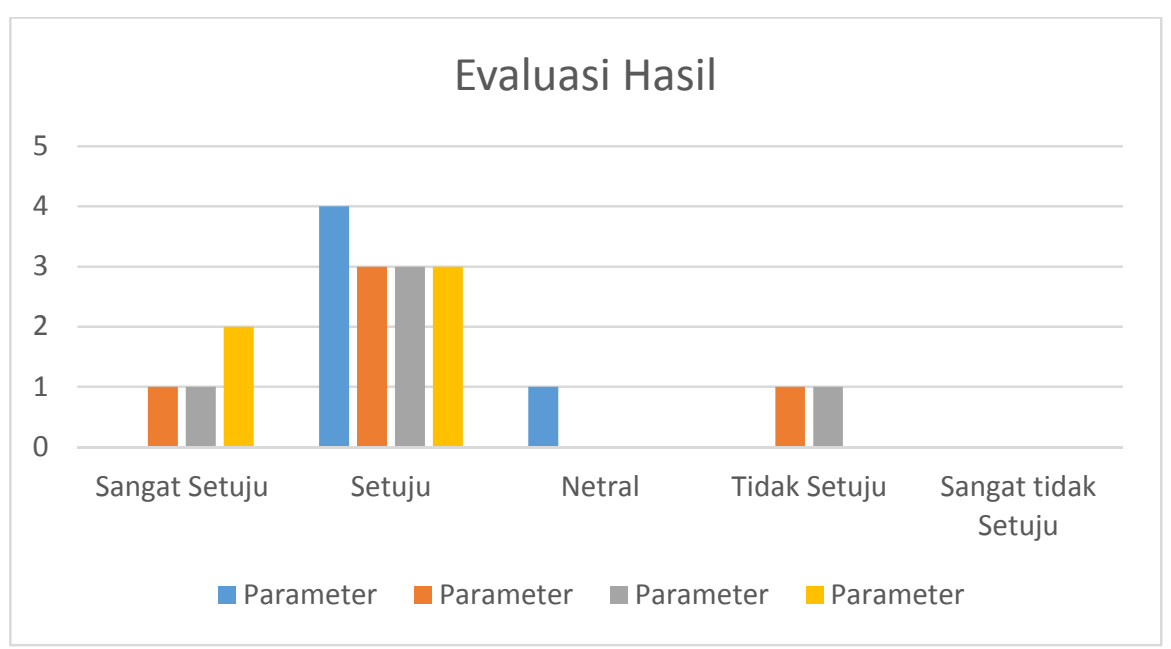

Gambar 11. Evaluasi Hasil Penelitian

Gambar 10 menunjukan hasil untuk survey/ hasil kuisioner pengguna, chart menunjukan hasil yang positif untuk setiap bagian dari pertanyaan dengan parameter kebermanfaatan aplikasi $(80 \%$ sangat setuju dan setuju bahwa aplikasi bermanfaat), parameter kemudahan dipelajari ( $80 \%$ setuju bahwa aplikasi mudah dipelajari), untuk parameter kemudahan penggunaan (100\% sangat setuju dan setuju bahwa aplikasi mudah untuk digunakan), sedangkan untuk parameter kepuasan pengguna (di atas $80 \%$ pengguna puas dalam menggunakan aplikasi tersebut). Hal ini mengindikasikan bahwa aplikasi ini dapat digunakan dan dapat membantu dalam pengarsipan data pasien pada klinik Cemara.

\section{KESIMPULAN}

Pengelolaan data di bidang kesehatan dewasa ini menjadi penting mengingat perkembangan teknologi yang semakin pesat. Khususnya di klinik proses pengarsipan data secara digital menjadi hal yang tidak bias diabaikan begitu saja dikarenakan pengelolaan data manual yang kurang efektif dan efisien baik dalam pencarian data maupun pembuatan laporan. Dalam penelitian yang telah dilakukan didapatkan sebuah sistem informasi pengarsipan data pasien yang berdasarkan hasil implementasi dan hasil evaluasi menunjukan bahwa aplikasi ini bermanfaat dan membantu dalam pengolahan data pasien di Klinik Cemara.

\section{SARAN}

Penelitian selanjutnya adalah mengembangkan sistem informasi pengarsipan agar lebih user friendly dan menambahkan beberapa fitur seperti pembuatan laporan dengan import ke excel ataupun pdf serta beberapa fitur untuk meningkatkan kinerja system informasi yang dibangun.

[1] H. Jogiyanto, Analisa dan Desain Sistem Informasi. Yogyakarta: Penerbit Andi, 2005.

[2] E. R.; Subhiyakto and D. W. Utomo, "Software Testing Techniques And Strategies Use In Novice Software Teams," J. SISFO, vol. 5, no. 5, 2016.

[3] E. R. Subhiyakto and M. Kamalrudin, "Customization of Requirements Modeling Tool For Software Engineering Education," Int. Symp. Res. Innov. Sustain., vol. 2014, no. October 2014, pp. 1581-1584, 2014.

[4] L. Zhi, "Design and implementation of the comprehensive archives information digital management system," 2012 2nd Int. Conf. Consum. Electron. Commun. Networks, CECNet 2012 - Proc., pp. 1764-1767, 2012.

[5] E. M. Sibarani, "Simulating an integration systems: Hospital information system, radiology information system and picture archiving and communication system," 
Proceeding 2012 Int. Conf. Uncertain. Reason. Knowl. Eng. URKE 2012, pp. 62-66, 2012.

[6] M. Berndtsson, J. Hansson, B. Olsson, and B. Lundell, Thesis Guide - A Guide for Students in Computer Science and Information Systems. 2008.

[7] D. W.; Utomo and E. R. Subhiyakto, "Assessing Novice Teams in Collaborative Software Engineering Education," in Seminar Nasional Aplikasi Teknologi Informasi (SNATi), 2016, pp. 23-28.

[8] A. Dennis, B. H. Wixom, and R. M. Roth, System Analysis and Design. 2012. 